\title{
INFANT'S SKIN AND CARE NEEDS WITH SPECIAL CONSIDERATION TO FORMULATION ADDITIVES
}

\author{
SIRI SINDHURA DK, VIKAS JAIN* \\ Department of Pharmaceutics, JSS College of Pharmacy, JSS Academy of Higher Education and Research, Mysore, Karnataka, India. \\ Email: vikasjain@jssuni.edu.in
}

Received: 10 July 2018, Revised and Accepted: 05 September 2018

\begin{abstract}
Infancy is the time of adaptation from intrauterine life to the rather dry and cold, environment. Infant skin is more sensitive due to the immature immune system, hence, effortlessly prone to complications. Children from different age groups face diverse skin problems such as cradle cap, infant eczema, diaper rash, prickly heat, and many more. During early infancy, the products such as mild cleansers and lotions are used, and later, massage oils, creams, lotions, soaps, bubble bath, and other products are utilized for another few years, as a part of routine care. The preterm infants are more prone to skin damage and percutaneous toxicity from topically applied products. The ingredients incorporated in infant care products require special attention while choosing a product for them. Topical application of any such product requires thorough screening for potentially harmful ingredients before its exposure to the infant's skin. Products used for infants should be safe and restricted of fragrance, coloring agents, parabens, plant oils, extracts, and other obnoxious ingredients. The literature is flooded with the list of safer excipients that can be utilized for the development of skin care products for infants and children.
\end{abstract}

Keywords: Dermatitis, Formulation additives, Dry skin, Skin structure, Skin barrier.

(C) 2018 The Authors. Published by Innovare Academic Sciences Pvt Ltd. This is an open access article under the CC BY license (http://creativecommons. org/licenses/by/4. 0/) DOI: http://dx.doi.org/10.22159/ajpcr.2018.v11i12.27384

\section{INTRODUCTION}

Infant skin is considered most delicate among all skin types [1]. The neonatal period states for the $1^{\text {st }}$ month after birth. A newborn baby is born with a protective covering which is wrinkly in nature, called vernix [2]. It naturally peels off during the $1^{\text {st }}$ week after birth. The anatomical features such as the presence of thin dermis, decreased cohesion between dermis and epidermis renders it more vulnerable to certain obnoxious stimuli and make it susceptible to certain common skin disorders such as Eczema, cradle cap, heat rash, diaper dermatitis, and other forms of dermatitis [3]

Baby's skin has special skin care needs to protect from common disorders. The formulations chosen for the baby skin require specific consideration [4]. Neonatal skin has peculiar absorption characteristics, with high permeability to topical agents. In the early neonatal period, there is a marked topical drug absorption and high skin water loss because of incomplete development of the stratum corneum [5,6]. On safety, this article discusses the baby skin structural features, the common skin disorders seen in babies, and skin care needs of a baby including the formulation excipients that are commonly recommended and avoided [7].

\section{SKIN FEATURES OF AN INFANT}

Functional and structural skin maturation is a dynamic process, which starts at the moment of delivery and ends in the $1^{\text {st }}$ year of life. In fullterm newborns, this process begins immediately after birth, while in preterm newborns by 2-3 weeks after birth, the skin is comparable to a full-term newborn's skin [8].

The skin comprises a multi-layered epidermis from ectoderm with an underlying dermis derived from mesoderm [9]. The skin further develops through the embryonic and fetal stage [10]. The epidermis also includes the basal layer and the superficial periderm [11]. Vernix caseosa is a protective hydrophobic layer that guards the fetal skin against intrauterine maceration. It is composed of water (80.5\%), proteins, sebum lipids, and antimicrobial peptides with biomechanical and water-binding properties [12].

\section{DIFFERENCES BETWEEN AN ADULT AND BABY'S SKIN}

Infant skin is often regarded as ideal skin, and adults normally seek its features [13]. Higher skin hydration, a lower skin $\mathrm{pH}$, relates to a reduced heat loss after birth. Pre-mature babies have an immature epidermal barrier and lack the protective coating of vernix caseosa; therefore, greater risk of having a lower body temperature [14]. Infant skin has a higher rate of water absorption and desorption compared to adults [15]. Newborns have a large surface area in relation to volume and a high thermal conductance with an increased risk of heat loss. They have less number of melanocytes, which results in less photo-protection of their skin, resulting in abnormal collagen and elastin levels [16]. Sebum levels in the $1^{\text {st }}$ week of life are high, which subsequently decrease [17]. The natural moisturizing factor is lower in infants compared to adults, but the level of NMF is reported to be higher in the first 2 weeks of life [18-20].

\section{COMMON SKIN DISORDERS SEEN IN BABIES}

\section{Diaper dermatitis}

A rash that occurs in the parts within the diaper in infants aged around $9-12$ months is usually termed as diaper dermatitis. Around $7-35 \%$ of the infant population suffer from diaper dermatitis [21].

Increased wetness in the diaper area results in increased susceptibility of baby's skin to physical, chemical damage, and some enzymatic mechanisms. Excess hydration causes the urease enzyme that is found in the stools to liberate ammonia, a mild irritant, which increases the $\mathrm{pH}$ and cause irritation to the skin [21]. Other enzymes such as lipases, proteases come in contact with the skin; they can also break down the skin barrier. The bile salts present in the feces boost the activity of enzymes, adding to the effect [22].

A fungus, Candida albicans can also contribute to augment diaper dermatitis. Other microbes have been secluded less often, as they occur as a result of secondary infections [23].

The treatment available in the market does comprise diaper rash creams which contain zinc oxide as their active ingredient as it dries the area, 
gives astringent and antiseptic effect. In case of persistent dermatitis, hydrocortisone cream with mild antifungal is recommended [25].

\section{Eczema}

Eczema or atopic eczema is a very common skin disorder among children, which is a form of skin rash that occurs on several parts of the body leaving the diaper area appearing usually before age 5 [26]. Around $20 \%$ suffers from itchy eczema [27]. The starting stage of eczema is usually just dry, patchy areas on the skin. If remains untreated, the condition may aggravate into dry, pus-covered inflamed skin. The right reason for the occurrence of atopic eczema is unidentified [28]

Due to frequent bathing of the baby, the natural oils present on the skin sap off, making it dry, leading to eczema [29,30]. Factors contributing include Ecological factors such as high humid temperatures, dust mites in the house, as a reaction to a vaccination, and presence of allergens such as soaps, creams, and detergents and can also be a viral infection [31,32].

Eczema can be treated by moisturizing the baby at regular intervals with thick creams containing emollients with an antiseptic or steroid cream. Emollients are available in various forms such as creams, lotions, ointments, and gels. Ointments with white soft paraffin and liquid paraffin, which are greasy and creams, lotions containing water are used for eczema [33,34].

\section{Miliaria}

Miliaria, also called prickly heat, is a very common disorder. It occurs due to high levels of heat and humidity. It is caused by obstruction of the sweat ducts, causing the eccrine sweat to leak into the epidermis [35].

Miliaria is classified into 3 types according to the level of obstruction of the sweat duct [36] Miliaria crystallina, Miliaria Rubra, and Miliaria profunda [37]. Excessive hydration of stratum corneum leads to transient blockage of sweat ducts because babies have immature eccrine sweat glands [38]. Resident skin bacteria, such as Staphylococcus epidermidis and Staphylococcus aureus, are thought to play a role in the pathogenesis of miliaria.

Although the prevention of exposure to hot and humid climate is the best measure to protect the infant skin from heat rash, treatment of a heat rash includes powdering the baby with a prickly heat baby powder containing zinc oxide and some natural cooling agents like menthol [39].

\section{Cradle cap}

Cradle cap or seborrheic dermatitis is very common to appear during baby's first 2 months, and it can stay for weeks or months [40]. Cradle cap looks like a bad case of dandruff. It can show up as crusty, greasy, and yellowish inflamed scales on the infant's scalp. Over time, the patches are going to become flaky, and they start rubbing off with bits of baby's hair attached [41].

The one contributing factor of cradle cap is known to be mother's hormones remained on the baby after birth. They stimulate the oil glands to secrete excess oil, which adheres onto the scalp and may take weeks or months to disappear by its own [42]. Another factor may be the presence of fungi, Malassezia that grows in the sebum along with bacteria. These fungi can cause infections that show up as severe dandruff [43].

Depending on the cause, the affected area can be treated by massaging it with natural baby oils and rinsing it off gently. For the treatment of fungal infection, antifungal preparations containing ketoconazole can be used [44].

\section{INFANT'S SKIN CARE NEEDS}

An infant's skin is categorized into - dry skin, oily skin, and combination and sensitive skin. Each skin type has special daily care needs specifically considering seasonal variations. It is known that an infant's
Table 1: The excipients recommended and to be avoided in the formulation of baby oils $[72-74,87,88,97,98]$

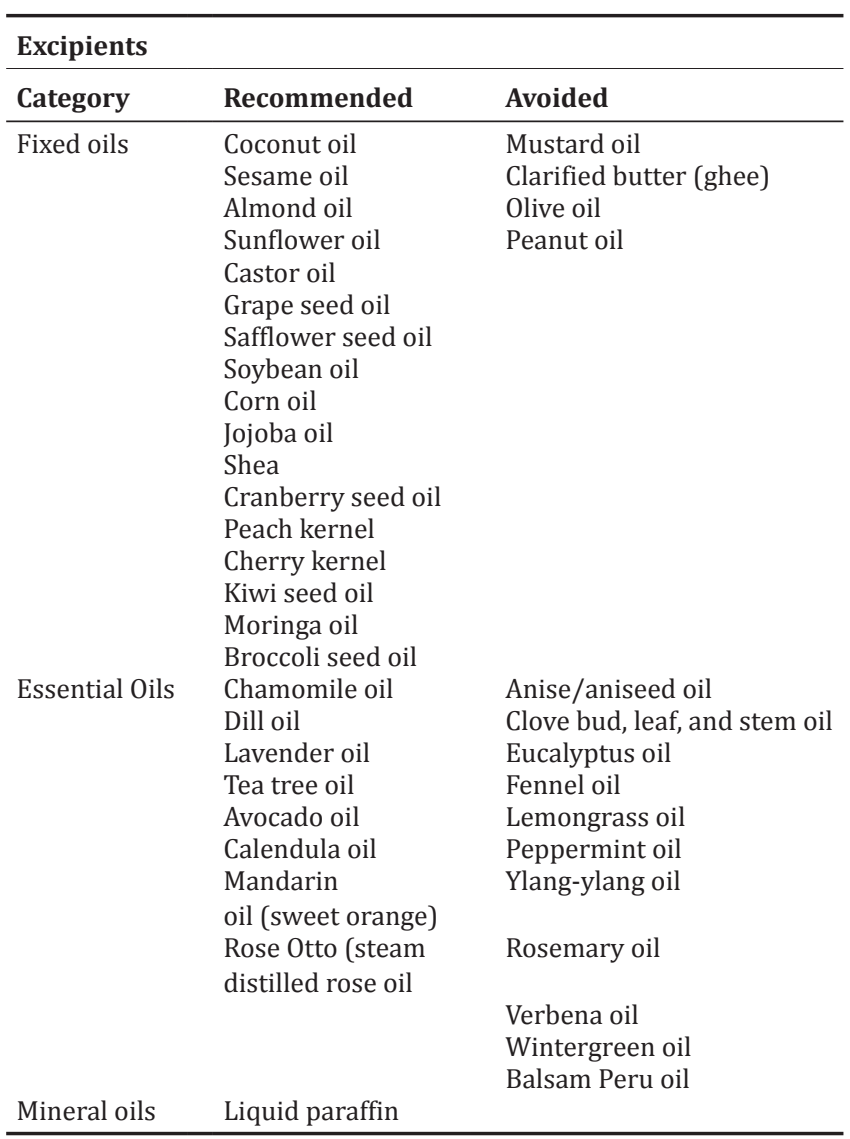

Table 2: The excipients recommended and to be avoided in the formulation of baby powders [72-74,93-95]

\begin{tabular}{lll}
\hline Excipients & & \\
\hline Category & Recommended & Avoided \\
\hline Bulking agents & $\begin{array}{l}\text { Cornstarch (natural and organic) } \\
\text { Tapioca starch }\end{array}$ & Talc \\
& Oat starch & \\
& Sodium bicarbonate & \\
& Bentonite & \\
& Kaolin & \\
Antibacterial & Zinc oxide & All \\
Antioxidant & Tocopheryl Acetate & All \\
Fragrance & None & \\
Dyes & None & \\
\hline
\end{tabular}

skin is different from adult skin. When it comes to seasonal variations, to protect their skin from various ailments, also in general day-to-day care and product considerations are given utmost importance $[45,46]$.

\section{Daily skin care}

The process of bathing dries out the infant's skin because it saps out the natural. Bathing time should be kept minimal, and the temperature of the water should remain optimum. In general, perfume and detergentfree soap is recommended [47].

To maintain the proper level of moisturization, moisturizing at regular intervals while there is still some moisture left on the skin from the bath helps to lock the water on the skin [48]. Use of emollients can be helpful to restore skin elasticity, sustain skin homeostasis, and control TEWL, while a regular emollient application from birth can be considered an effective approach for atopic dermatitis prevention in neonates [49]. 
Changing lifestyles cause babies in need of disposable diapers and wipes which are convenient for parents. Airing out the diaper area is very important to prevent moisture accumulation. Constant use of diapers may cause redness, leading to diaper dermatitis in most cases [50]. Baby products contain mild cleansers and protect the natural balance of baby's skin. Skin care products made for babies should have lower levels of chemicals, fragrance, and dyes [51].

\section{Summer care}

The heat alleviates the perspiration, which leads to skin infections in infants [52]. Sweat contains sodium chloride in it causing rashes and itching [53,54]. Cradle cap can be a sign of fungal infection, and certain antifungal preparations on baby's head can be used. Application of oil is avoided if dermatitis or heat rash is seen along with cradle cap [55]. Heat rash is commonly observed during summer. Prickly heat powders with zinc oxide are widely used [56]. If sweating is heavy and fungal infection is seen, the best way to manage would be using dusting powders $[57,58]$.

\section{Winter care}

Winter can seem very harsh on infant's sensitive skin. During winter, their skin tends to become dry forming wrinkles $[59,60]$. Applying any baby massage oil all over the baby's scalp and massaging gently can remove dandruff from the scalp caused due to winters [61]. Safe, low-dose, and hydrocortisone can be used for heat rashes due to over-clothing [62]. Any signs of eczema, ointments can be used as moisturizers after baths. For good results, oils are massaged at regular intervals, which increases the penetration of oil into the skin $[63,64]$.

\section{FORMULATION ESSENTIALS FOR INFANT'S SKIN CARE PRODUCTS}

The market is filled with various baby care products such as baby oils, shampoos, soaps, and creams. To choose the right product for your baby skin is a challenge, as they have to meet certain criteria such as being mild and non-toxic. However, not all the ingredients that are present in baby products are harmful. Therefore, the excipients considered harmful should be avoided in baby products. This section discusses the excipients that are usually recommended to use and should be avoided in infant's products.

\section{Baby oils}

Baby oils are mineral or natural oil or combination of these categories used for applying on baby skin or scalp to moisturize. Massaging baby oils is to strengthen the muscles and relax them. Oil massage of newborns has been practiced for generations. However, oils may vary from potentially beneficial, for example, sunflower seed oil, and to potentially toxic, for example, mustard oil (Table 1). Among all oils,

Table 3: The excipients recommended and to be avoided in the formulation of baby shampoo $[72-74,96]$

\begin{tabular}{|c|c|c|}
\hline \multicolumn{3}{|l|}{ Excipients } \\
\hline Category & Recommended & Avoided \\
\hline \multirow[t]{13}{*}{ Surfactants } & Sodium Trideceth Sulfate & Sodium lauryl sulfate \\
\hline & Cocamidopropyl betaine & Sodium laureth sulfate \\
\hline & Disodium cocoamphodiacetate & Ammonium laureth sulfate. \\
\hline & Coco-glucoside & Carboxylates \\
\hline & Decyl glucoside & Quaternary ammonium salts \\
\hline & Lauryl glucoside & Amine oxides \\
\hline & Sucrose Laurate & Sulfoxides \\
\hline & Glyceryl oleate & Ethoxylates \\
\hline & Sodium lauroamphoacetate & Poloxamers \\
\hline & Betaine & \\
\hline & Sorbitan Laurate & \\
\hline & Sodium Cocoyl Isethionate & \\
\hline & Sodium coco sulfate & \\
\hline \multirow{2}{*}{$\begin{array}{l}\text { Conditioning } \\
\text { Agent }\end{array}$} & Polyquaternium-10 & Dimethicone \\
\hline & $\begin{array}{l}\text { Guar Hydroxy- propyl trimonium Chloride } \\
\text { Butylene Glycol } \\
\text { Capryloyl glycine } \\
\text { PCA Glyceryl oleate }\end{array}$ & Silicones \\
\hline Foamer & Disodium oleamide & \\
\hline Thickener & PEG-80 & Sodium chloride \\
\hline Preservatives & $\begin{array}{l}\text { Sodium Benzoate } \\
\text { Glucose oxidase and lactoperoxidase } \\
\text { Phenoxyethanol } \\
\text { Potassium sorbate }\end{array}$ & $\begin{array}{l}\text { Parabens: Methyl paraben, propyl paraben etc. } \\
\text { Formaldehyde donors }\end{array}$ \\
\hline Humectant & $\begin{array}{l}\text { Glycerine } \\
\text { Calcium gluconate }\end{array}$ & Propylene glycol \\
\hline $\begin{array}{l}\text { Chemical } \\
\text { Fragrances }\end{array}$ & None & $\begin{array}{l}\text { Acetaldehyde, Benzophenone, BHA, Benzyl Salicylate, Benzyl Benzoate, } \\
\text { Butoxyethanol, Butylphenyl methylpropional, Chloromethane (methyl } \\
\text { chloride), Dichloromethane (methylene chloride), DEP, Eugenyl methyl ether } \\
\text { (Methyleugenol), Formaldehyde, MEA, DEA, TEA-ethanolamines, Oxybenzone } \\
\text { (BP-3), Methanol, Synthetic Musks (Tonalide, Galaxolide, Musk Ketone, Musk } \\
\text { Xylene) etc. }\end{array}$ \\
\hline \multicolumn{3}{|r|}{-5} \\
\hline Other & Glucose (natural exfoliate) & Isopropyl alcohol (solvent) \\
\hline \multirow[t]{4}{*}{ Excipients } & Citric Acid (pH stabilizer) & \\
\hline & Sodium Hydroxide (relaxer) & \\
\hline & Allyl caproate (emollient) & \\
\hline & Triethyl citrate (masking) & \\
\hline
\end{tabular}

BHA: Butylated hydroxyanisole, DEP: Diethyl phthalate 
Table 4: The excipients recommended and to be avoided in the formulation of creams and lotions $[72-74,93]$

\begin{tabular}{|c|c|c|}
\hline \multicolumn{3}{|l|}{ Excipients } \\
\hline Category & Recommended & Avoided \\
\hline \multirow[t]{12}{*}{ Emulsifiers } & Cetyl palmitate & $\begin{array}{l}\text { Propylene glycol (1,2-propanediol, methyl ethyl glycol, 1,2-propylene glycol), } \\
\text { 2-bromo- } 2 \text { nitropropane-1,3- diol) }\end{array}$ \\
\hline & Sorbitan Palmitate & Triethanolamine \\
\hline & Ricinus Communis Seed Oil & Steareth- 20 \\
\hline & Mineral Oil & \\
\hline & Capric Triglyceride & \\
\hline & Sorbitan Olivate & \\
\hline & Petrolatum & \\
\hline & Decyl Oleate & \\
\hline & Ascorbyl Palmitate & \\
\hline & Stearic acid & \\
\hline & Beeswax & \\
\hline & Polysorbate 60 & \\
\hline Humectant & Glycerine & \\
\hline \multirow[t]{3}{*}{ Alcohols } & Cetyl Alcohol & Isopropyl alcohol \\
\hline & Cetearyl Alcohol & Ethyl alcohol \\
\hline & & Benzyl alcohol \\
\hline \multirow[t]{6}{*}{ Emollient } & Glyceryl Stearate & Cyclopentasiloxane \\
\hline & PEG-40 Stearate & \\
\hline & Caprylyl Glycol & \\
\hline & Glyceryl caprylate & \\
\hline & Caprylyl alcohol & \\
\hline & Lecithin & \\
\hline \multirow[t]{5}{*}{ Preservative } & Phenoxyethanol & Parabens \\
\hline & Sodium benzoate & Formaldehyde donors \\
\hline & Sorbic acid & $\begin{array}{l}\text { Phthalates: (Di (2-ethylhexyl) phthalate (DEHP Di (2-ethylhexyl) phthalate (DEHP), } \\
\text { dioctyl phthalate (DOP), and bis (2-ethylhexyl) phthalate (BEHP)). }\end{array}$ \\
\hline & & Methylisothiazolinone and methylchloroisothiazolinone \\
\hline & & Diazolidinyl urea and Imidazolidinyl urea \\
\hline \multirow{6}{*}{$\begin{array}{l}\text { Other } \\
\text { Excipients }\end{array}$} & Citric acid (pH stabilizing agent) & Ethylhexylglycerin (conditioning agent) \\
\hline & & \\
\hline & $\begin{array}{l}\text { Dimethicone (conditioning } \\
\text { agent) }\end{array}$ & Potassium lactate (conditioning agent) \\
\hline & Bentonite (emulsion stabilizer) & \\
\hline & $\begin{array}{l}\text { Tocopheryl acetate (skin } \\
\text { conditioning) }\end{array}$ & \\
\hline & Zinc oxide ( diaper rash) & \\
\hline Chemical & None & Linalool \\
\hline Fragrances & & Hexyl cinnamal \\
\hline Dyes & None & All \\
\hline
\end{tabular}

coconut oil and sunflower oil have been most widely used for infant massage $[65,66]$. Sunflower oil protects the integrity of stratum corneum and improves hydration [67]. Olive oil can promote atopic dermatitis and aggravate existing dermatitis [70].

Ahmed et al. 2007 suggested that those who received an oil massage, the most commonly-used product was mustard oil, which was applied to $73(88 \%)$ of the 83 babies massaged; other products mentioned were coconut oil in eight (9.6\%) cases, and olive oil, and proprietary baby lotion in one each. In this study, the "mean oxygen saturation" was enhanced in babies massaged with sunflower oil [68].

In general, vegetable oils that are high in linoleic acid are gentler on baby skin. Linoleic acid is an essential fatty acid that helps to protect the barrier of skin, for example, Sunflower oil and grape seed oil. Vegetable oils high in oleic acid may be harsher on your baby's skin, for example, olive oil. Perfume-free baby mineral oils are another option if your baby has dry, broken skin. Mineral oil is derived from petroleum [69,70]. Petroleum-based skin softeners (emollients) are effective and safe for treating skin problems such as dermatitis and eczema (Table 1).

\section{Powders}

Powders are generally used to control excess moisture due to sweat and to reduce the friction between skin [76]. The talcum-based baby powder is prepared from the mineral talc, which comprises mostly silicon, magnesium, and oxygen. It absorbs moisture and decreases friction between skin, which helps avert rashes especially diaper rash. Talcum powder contains two main ingredients: Talc and fragrance [77]. Baby powders contain either talc or corn starch as the moisture-absorbing ingredient (Table 2). Medicated powders used for diaper rash contain zinc oxide in the powders. This acts as an antibacterial as well as an astringent (Table 2).

\section{Baby shampoo}

Baby shampoo is a baby hair care product employed to remove the dirt, oil, dandruff, and other particles from the scalp. The ingredients used for baby shampoo are milder when compared to an adult shampoo [78]. The building blocks of shampoo include - surfactants, thickeners, foaming agents, preservatives, and conditioning agents (Table 3).

The $\mathrm{pH}$ of 6-7 and ideally should contain only mild surfactants such as mixtures of non-ionic and amphoteric substances or mild anionics such as sulfosuccinates, isethionates, and protein fatty acids condensates $[79,80]$. It should contain ingredients that are harmless to the scalp, hair, as well as less irritating to the eyes. To avoid eye-contact, the viscosity of the shampoo could be increased (Table 3).

\section{Creams and lotions}

Creams and lotions are semi-solid dosage forms that are applied topically and provide a protective layer around the body, keep moisture 
Table 5: The excipients recommended and to be avoided in the formulation of a bubble bath. [72-74,97]

\begin{tabular}{lll}
\hline Excipients & & \\
\hline Category & Recommended & Avoided \\
\hline Surfactants & Sodium lauryl glycol carboxylate & Sodium lauryl sulfate \\
& Sodium cocoyl alkyl Esters & Sodium laureth sulfate \\
& Decyl glucoside & Ammonium laureth sulfate \\
& Lauryl glucoside & Carboxylates \\
& Disodium cocoamphodiacetate & Quaternary ammonium salts \\
& Disodium-coco glucoside sulfosuccinate & Amine oxides \\
& Glyceryl Oleate & Sulfoxides \\
& Coco- glucoside & Ethoxylates \\
& Sodium Lauroamphoacetate & Poloxamers \\
& Betaine & \\
Foamer & Sorbitan Laurate & \\
Humectant & Sodium cocoyl Isethionate & \\
Emollient & Sodium-coco sulfate & \\
& Disodium oleamide & \\
Glycerine & Propylene glycol \\
Preservatives & Gluconolactone & Cyclopentasiloxane \\
& Caprylyl glycol & \\
Other Excipients & Caprylyl glycol & Parabens \\
& Glyceryl caprylate & Formaldehyde donors \\
\hline & Sodium benzoate & Phthalates \\
& Phenoxyethanol & Ethylhexyl glycerine (conditioning agent) \\
\hline
\end{tabular}

Table 6: The excipients recommended and to be avoided in the formulation of baby soap [72-74,98]

\begin{tabular}{|c|c|c|}
\hline \multicolumn{3}{|l|}{ Excipients } \\
\hline Category & Recommended & Avoided \\
\hline \multirow[t]{9}{*}{ Fats/oils } & Saponified olive oil & \\
\hline & Saponified coconut oil [99] & \\
\hline & Saponified palm oil & \\
\hline & Cocoa butter & \\
\hline & Sodium palmate & \\
\hline & Citrus peel oil & \\
\hline & Sodium olivate & \\
\hline & Saponified castor oil & \\
\hline & Potassium chocolate & \\
\hline \multirow[t]{2}{*}{ Alkali } & Potassium hydroxide & \\
\hline & Sodium chloride & \\
\hline Humectants & Glycerine & Propylene glycol \\
\hline \multirow[t]{9}{*}{ Surfactant } & $\begin{array}{l}\text { Sodium myristoyl } \\
\text { sarcosinate }\end{array}$ & Sodium lauryl sulfate \\
\hline & Sodium lauroamphoacetate & Sodium laureth sulfate \\
\hline & Cocoamphoacetate & $\begin{array}{l}\text { Ammonium laureth } \\
\text { sulfate }\end{array}$ \\
\hline & Palm acid & Carboxylates \\
\hline & Polyglycerol 2-oleyl ether & $\begin{array}{l}\text { Quaternary } \\
\text { ammonium salts }\end{array}$ \\
\hline & Glutamate & Amine oxides \\
\hline & Glucosides & Sulfoxides \\
\hline & & Ethoxylates \\
\hline & & Poloxamers \\
\hline \multirow[t]{3}{*}{ Preservatives } & Sorbates & Parabens \\
\hline & Phenoxyethanol & Formaldehyde donors \\
\hline & Sodium benzoate [100] & Phthalates \\
\hline
\end{tabular}

in, and toxin out regulates body temperature. Lotions are lighter and low viscous than creams. Moisturizing the baby is very vital irrespective of the seasons [85]. It helps to seal or lock the moisture on the skin to keep it soft and supple. In case of starting skin damage, water-in-oil (w/o) creams or water-free ointments with talc, kaolin, and zinc oxide as actives are advised. During winter, barrier creams protect baby's face from freezing cold and wind. The lipid phase often contains petrolatum.
These barrier creams are effective around the nose and mouth. They usually also contain moisturizers, soothing active ingredients, and nonionic emulsifiers [93].

Ingredients used for formulating baby creams and lotions should be mild and non-irritating. They should moisturize the skin and give an emollient action (Table 4). The $\mathrm{pH}$ of the cream/lotion should be maintained around $\mathrm{pH} 6.5$ and should be scrutinized for dermal and ocular safety, including clinical assessment for dermal irritation, dermal sensitization potential, and ocular irritation (Table 4).

\section{Bubble bath}

A bubble bath is a filled bathtub with a layer of surfactant foam on the surface of the water and consequently the surfactant product used to produce the foam. Less commonly, aerated or carbonated baths are called bubble baths. Mixtures of surfactants, foam stabilizers, emollients, humectants are the main constituents of bubble bath formulation. The surfactants used in bubble baths should be mild. It should not contain any chemical fragrances [97] (Table 5).

\section{Baby soap}

Baby soap is the salt of fatty acid, which is used for cleansing the baby and should leave the baby skin moisturized [98]. It should cleanse the dirt and oils properly from the skin it should contain ingredients that should be non-irritable, scent and dye free. The fatty acids used for the baby soap are usually obtained from natural oils such as saponified olive oil and coconut oil (Table 6).

\section{CONCLUSION}

The delicate skin of infants can be considered as the biggest challenge for formulation scientist because the diversity associated with different skin types again poses a significant constraint for selecting safer formulation ingredients. Although this review incorporates a better insight into care as well as formulation needs, the ingredients incorporated in infant care products requires thorough screening for their safety. Products used for infant's care should be safe and free of fragrance, coloring agents, synthetic preservatives, and any unexplored natural and synthetic material. Although it is an era of herbal cosmetics, the herbal ingredients should not be accepted blindly, as formulation additives. 


\section{REFERENCES}

1. Fluhr JW, Darlenski R, Taieb A, Hachem JP, Baudouin C, Msika P, et al. Functional skin adaptation in infancy - Almost complete but not fully competent. Exp Dermatol 2010;19:483-92.

2. Shwayder T, Akland T. Neonatal skin barrier: Structure, function, and disorders. Dermatol Ther 2005;18:87-103.

3. Darmstadt GL, Dinulos JG. Neonatal skin care. Pediatr Clin North Am 2000;47:757-82.

4. LeFevre A, Shillcutt SD, Saha SK, Ahmed AS, Ahmed S, Chowdhury MA, et al. Cost-effectiveness of skin-barrier-enhancing emollients among preterm infants in Bangladesh. Bull World Health Organ 2010;88:104-12.

5. Nikolovski J, Stamatas G, Kollias N, Wiegand B. Infant skin barrier maturation in the first year of life. J Am Acad Dermatol 2007;56 suppl. 2: AB153.

6. Harpin VA, Rutter N. Barrier properties of the new-born infant's skin. J Pediatr 1983;102:419-25.

7. Blume-Peytavi U, Cork MJ, Faergemann J, Szczapa J, Vanaclocha F, Gelmetti C, et al. Bathing and cleansing in newborns from day 1 to first year of life: Recommendations from a European round table meeting. J Eur Acad Dermatol Venereol 2009;23:751-9.

8. Available from: https://www.pharmatutor.org/articles/baby-products.

9. Stamatas GN, Nikolovski J, Luedtke MA, Kollias N, Wiegand BC. Infant skin microstructure assessed in vivo differs from adult skin in organization and at the cellular level. Pediatr Dermatol 2010;27:125-31.

10. Afsar FS. Skin care for preterm and term neonates. Clin Exp Dermatol 2009;34:855-8.

11. Matiz C, Tom WL, Eichenfield LF, Pong A, Friedlander SF. Children with atopic dermatitis appear less likely to be infected with community acquired methicillin-resistant Staphylococcus aureus: The san diego experience. Pediatr Dermatol 2011;28:6-11.

12. Quesada-Cortés A, Campos-Muñoz L, Díaz-Díaz RM, Casado-Jiménez M. Cold panniculitis. Dermatol Clin 2008;26:485-9.

13. Mallory SB, Colven R. Disorders of subcutaneous tissue in the newborn. In: Harper J, Oranje AP, Prose NS, editors. Textbook of Pediatric Dermatology. America: Wiley-Blackwell; 2006.

14. Rissmann R, Groenink HW, Weerheim AM, Hoath SB, Ponec M, Bouwstra JA, et al. New insights into ultrastructure, lipid composition and organization of vernix caseosa. J Invest Dermatol 2006;126:1823-33.

15. Torrelo A, Hernández A. Panniculitis in children. Dermatol Clin 2008;26:491-500.

16. Bryanton J, Walsh D, Barrett M, Gaudet D. Tub bathing versus traditional sponge bathing for the newborn. J Obstet Gynecol Neonatal Nurs 2004;33:704-12.

17. Garcia Bartels N, Mleczko A, Schink T, Proquitté H, Wauer RR, Blume-Peytavi $\mathrm{U}$, et al. Influence of bathing or washing on skin barrier function in newborns during the first four weeks of life. Skin Pharmacol Physiol 2009;22:248-57.

18. Shoaeib FM, All SA, El-Barrawy MA. Alcohol or traditional methods versus natural drying for newborn's cord care. J Egypt Public Health Assoc 2005;80:169-201.

19. Blume-Peytavi U, Cork MJ, Faergemann J, Szczapa J, Vanaclocha F, Gelmetti C, et al. Bathing and cleansing in newborns from day 1 to first year of life: Recommendations from a European round table meeting. J Eur Acad Dermatol Venereol 2009;23:751-9.

20. Pustisek N, Sikanić-Dugić N, Hirsl-Hećej V, Domljan ML. Acute skin sun damage in children and its consequences in adults. Coll Antropol 2010;34 Suppl 2:233-7.

21. Truhan AP. Sun protection in childhood. Clin Pediatr (Phila) 1991;30:676-81.

22. Visscher MO, Narendran V, Pickens WL, LaRuffa AA, Meinzen-Derr J, Allen $\mathrm{K}$, et al. Vernix caseosa in neonatal adaptation. J Perinatol 2005;25:440-6.

23. Nikolovski J, Stamatas GN, Kollias N, Wiegand BC. Barrier function and water-holding and transport properties of infant stratum corneum are different from adult and continue to develop through the first year of life. J Invest Dermatol 2008;128:1728-36.

24. Smales OR, Kime R. Thermoregulation in babies immediately after birth. Arch Dis Child 1978;53:58-61.

25. Fluhr JW, Darlenski R, Lachmann N, Baudouin C, Msika P, De Belilovsky $\mathrm{C}$, et al. Infant epidermal skin physiology: Adaptation after birth. Br J Dermatol 2012;166:483-90.

26. Felter SP, Carr AN, Zhu T, Kirsch T, Niu G. Safety evaluation for ingredients used in baby care products: Consideration of diaper rash. Regul Toxicol Pharmacol 2017;90:214-21.
27. Ludriksone L, Bartels NG, Kanti V, Blume-Peytavi U, Kottner J. Diaper dermatitis: A study of contributing factors. Contact Derm 2009;26,248-52.

28. Liu N, Wang X, Odio M. Frequency and severity of diaper dermatitis with use of traditional Chinese cloth diapers: Observations in 3- to 9-month-old children. Pediatr Dermatol 2011;28:380-6.

29. Miyauchi Y, Shimaoka Y, Fujimura T, Koike Y, Yatabe M, Nishikawa $\mathrm{M}$, et al. Developmental changes in neonatal and infant skin structures during the first 6 months: In vivo observation. Pediatr Dermatol 2016;33:289-95

30. Australasian Society of Clinical Immunology and Allergy, Eczema (atopic dermatitis). Balgowlah, NSW: ASCIA; 2013. Available from: http://www.allergy.org.au/patients/skin-allergy/eczema.

31. Hay WW, Levin RJ. Deterding RR, Abzug MJ. Current Diagnosis and Treatment Pediatrics. 22 ${ }^{\text {nd }}$ ed. New York: McGraw-Hill Education Medical; 2014.

32. Phillips R, Orchard D. Dermatologic conditions. In: Gwee A, Rimmer R, Marks M, editors. Paediatric Handbook. $9^{\text {th }}$ ed. Melbourne: Wiley-Blackwell; 2015. p. 250-64.

33. Royal Children's Hospital Clinical Guidelines (nursing): Eczema Management. Melbourne: RCH; 2013. Available from: http://www.rch. org.au/rchcpg/hospital clinical guideline index/Eczema managemet.

34. Thaçi D, Salgo R. Malignancy concerns of topical calcineurin inhibitors for atopic dermatitis: Facts and controversies. Clin Dermatol 2010;28:52-6.

35. Williams HC, Grindlay DJ. What's new in atopic eczema? An analysis of systematic reviews published in 2007 and 2008- Part 1. Definitions, causes and consequences of eczema. Clin Exp Dermatol 2010;35:12-5.

36. Champion RH, Burton JL, Burns DA, Breathnach SM. Disorders of sweat glands. In: Textbook of Dermatology. $6^{\text {th }}$ ed. Malden, Mass: Blackwell Scientific Publications; 1998. p. 1997-9.

37. Wenzel FG, Horn TD. Nonneoplastic disorders of the eccrine glands. J Am Acad Dermatol 1998;38:1-7.

38. Cui CY, Ishii R, Campbell DP, Michel M, Piao Y, Kume T, et al. Foxc1 ablated mice are anhidrotic and recapitulate features of human miliaria sweat retention disorder. J Invest Dermatol 2017;137:38-45.

39. Moosavi Z, Hosseini T. One-year survey of cutaneous lesions in 1000 consecutive Iranian newborns. Pediatr Dermatol 2006;23:61-3.

40. Huda M, Saha P. Pattern of dermatosis among pediatric patients attending a medical college hospital in Northeastern region of India. Indian J Dermatol 2009;49:189.

41. Arpey CJ, Nagashima-Whalen LS, Chren MM, Zaim MT. Congenital miliaria crystallina: Case report and literature review. Pediatr Dermatol 1992;9:283-7.

42. Straka BF, Cooper PH, Greer KE. Congenital miliaria crystallina. Cutis 1991;47:103-6.

43. Haas N, Martens F, Henz BM. Miliaria crystallina in an intensive care setting. Clin Exp Dermatol 2004;29:32-4.

44. Tey HL, Tay EY, Cao T. In vivo imaging of miliaria profunda using highdefinition optical coherence tomography: Diagnosis, pathogenesis, and treatment. JAMA Dermatol 2015;151:346-8.

45. American Academy of Pediatrics: Healthy Children. Cradle cap. Available from: https://www.healthychildren.org/English/ages-stages/ baby/bathing-skin-care/Pages/Cradle-Cap.aspx.

46. Cradle Cap and Seborrheic Dermatitis in Infants; 2015. Available from: http://www.uptodate.com/contents/cradle-cap-and-seborrheicdermatitis-in-infants.

47. Mayo Clinic Staff. Cradle Cap; 2015. Available from: http://www. mayoclinic.org/diseases-conditions/cradle-cap/manage/ptc-20156936.

48. Mike P. All You Need to Know About Cradle Cap. Medical News Today; 2018. MediLexicon, Intl. On Web; 2018. Available from: https://www.medicalnewstoday.com/articles/218942.php.

49. Garoo R. Cradle Cap: Causes, Symptoms and Treatment; 2018.

50. VandenBerg KA. Basic principles of developmental caregiving. Neonatal Netw 1997;16:69-71.

51. You and Your Baby on the Special Care Baby Unit. Prof Nurse 1991;6:521-3.

52. Lawton $\mathrm{S}$. Understanding skin care and skin barrier function in infants. Nurs Child Young People 2013;25:28-33.

53. Lavender T, Bedwell C, Tsekiri-O'Brien E. A qualitative study exploring women's and health professionals' views of newborn bathing practices. Evid Based Midwife 2009;7:112-21.

54. Simpson EL, Chalmers JR, Hanifin JM, Thomas KS, Cork MJ, McLean WH, et al. Emollient enhancement of the skin barrier from birth offers effective atopic dermatitis prevention. J Allergy Clin Immunol 2014;134:818-23.

55. NICE. Nappy Rash. National Institute for Health and Care Excellence. 
Clinical Knowledge Summaries; 2014. Available from: http://www. cks.nice.org.uk.

56. NICE. Dermatitis - Contact. National Institute for Health and Care Excellence. Clinical Knowledge Summaries; 2014. Available from: http://www.cks.cks.nice.org.uk.

57. Scheinman PL. Exposing covert fragrance chemicals. Am J Contact Dermat 2001;12:225-8

58. Guhasarkar S. Simple Tips to Make Your Baby Comfortable In Summers; 2015.

59. Stamatas GN, de Sterke J, Hauser M, von Stetten O, van der Pol A. Lipid uptake and skin occlusion following topical application of oils on adult and infant skin. J Dermatol Sci 2008;50:135-42.

60. Darmstadt GL, Mao-Qiang M, Chi E, Saha SK, Ziboh VA, Black RE, et al. Impact of topical oils on the skin barrier: Possible implications for neonatal health in developing countries. Acta Paediatr 2002;91:546-54.

61. NHS Choices. Prickly Heat. NHS Choices, Health A-Z; 2014. Available from: https://www.nhs.uk/news/2007/August/Pages/NHSChoices. aspx. [Last accessed on 2018 Jan 20].

62. NHS Choices. Heat Exhaustion and Heatstroke NHS Choices, Health A-Z; 2015. Available from: https://www.nhs.uk/conditions/heatexhaustion-heatstroke. [Last accessed on 2018 Jan 20].

63. White J. How to Care for Your Baby's Skin in the Winter; 2017.

64. Van Onselen J. Skincare for infants: An evidence-based review. J Fam Health Care 2013;23:29-30

65. AWHONN. Neonatal Skin Care. Association of Women's Health, Obstetric and Neonatal Nurses. Washington: Evidence-Based Clinical Practice Guideline. $3^{\text {rd }}$ ed; 2013.

66. Mason R. What Goes With Eczema? A Review of Clothing Materials and Their Effect on Eczematous Skin; 2012. Available from: http:// www.talkhealthpartnership.com

67. Kulkarni A, Kaushik JS, Gupta P, Sharma H, Agrawal RK. Massage and touch therapy in neonates: The current evidence. Indian Pediatr 2010;47:771-6.

68. Mullany LC, Darmstadt GL, Khatry SK, Tielsch JM. Traditional massage of newborns in Nepal: Implications for trials of improved practice. J Trop Pediatr 2005;51:82-6.

69. Danby SG, AlEnezi T, Sultan A, Lavender T, Chittock J, Brown K, et al. Effect of olive and sunflower seed oil on the adult skin barrier: Implications for neonatal skin care. Pediatr Dermatol 2013;30:42-50.

70. Ahmed AS, Saha SK, Chowdhury MA, Law PA, Black RE, Santosham M, et al. Acceptability of massage with skin barrierenhancing emollients in young neonates in bangladesh. J Health Popul Nutr 2007;25:236-40.

71. Verallo-Rowell VM, Dillague KM, Syah-Tjundawan BS. Novel antibacterial and emollient effects of coconut and virgin olive oils in adult atopic dermatitis. Dermatitis 2008;19:308-15.

72. Ang JY, Lua JL, Mathur A, Thomas R, Asmar BI, Savasan S, et al. A randomized placebo-controlled trial of massage therapy on the immune system of preterm infants. Pediatrics 2012;130:e1549-58.

73. EU. 2008. Guidance Note: Labelling of Ingredients in Cosmetic Directive 76/768/EEC European Union; 2014.

74. CTPA. The Facts About a Guide to Cosmetics for Parents. The Cosmetics, Toiletry and Perfumery Association; 2010.

75. 20 Brilliant Uses for Baby Powder You've Never Considered. Available: https://www.diyncrafts.com/7271/lifehacks/20-brilliant-uses-for-babypowder.

76. Whysner J, Mohan M. Perineal application of talc and cornstarch powders: Evaluation of ovarian cancer risk. Am J Obstet Gynecol 2000;182:720-4.

77. Trüeb RM. Shampoos: Composition and clinical applications. Hautarzt 1998;49:895-901.

78. Dhar S. Newborn skin care revisited. Indian J Dermatol 2007;52:1-4.

79. Warren R, Ertel KD, Bartolo RG, Levine MJ, Bryant PB, Wong LF, et al. The influence of hard water (calcium) and surfactants on irritant contact dermatitis. Contact Dermatitis 1996;35:337-43.

80. Blume-Peytavi U, Hauser M, Stamatas GN, Pathirana D, Bartels NG. Skin care practices for newborns and infants: A review of the clinical evidence for best practices. Pediatr Dermatol 2012;29:1-14.

81. Schueller R, Romanowski P. Conditioning Agents for Hair and Skin. Boca Raton, FL, USA: CRC Press; 1999. p. 228

82. Attarzadeh Y, Asilian A, Shahmoradi Z, Adibi N. Comparing the efficacy of emu oil with clotrimazole and hydrocortisone in the treatment of seborrheic dermatitis: A clinical trial. J Res Med Sci 2013;18:477-81.

83. Barel AO, Paye M, Maibach H. Handbook of Cosmetic Science and Technology. $2^{\text {nd }}$ ed. New York: CRC Press; 2001. p. 715-22.

84. The Pittsburgh Press - Google News Archive; 1946. Available from: http://www.News.google.com.

85. Blume-Peytavi U, Cork MJ, Faergemann J, Szczapa J, Vanaclocha F, Gelmetti C, et al. Bathing and cleansing in newborns from day 1 to first year of life: Recommendations from a European round table meeting. J Eur Acad Dermatol Venereol 2009;23:751-9.

86. American Cleaning Institute. Available from: https://www. cleaninginstitute.org/clean_living/soaps_detergents_safety.aspx.

87. The Hazards of Mineral Oil Based Baby Oils and the Benefits of Natural Baby Oils. Available from: https://www.beautybythebatch. com/articles/naturalbabyoils.asp.

88. By Christina, Safe Essential Oil Use with Babies and Children; 2014. Available from: http://www.thehippyhomemaker.com/essential-oilsafety-babies-children.

89. Baby Powder, Talcum Powder, and Other Baby Powder Questions Answered 2015. Available from: https://www.babypibu.com/is-babypowder-talcum-powder-and-other-baby-powder-questions-answered.

90. By American Cancer Society Medical and Editorial Content Team. Talcum Powder and Cancer; 2017. Available from: https://www.cancer. $\mathrm{org} /$ cancer/cancer-causes/talcum-powder-and-cancer.html\#written by.

91. Kirschner C. 5 Alternatives to Talc Powder; 2017. Available from: https://www.mnn.com/health/fitness-well-being/stories/5-alternativestalc-powder.

92. Stephanie, Homemade Calming Baby Powder; 2014. Available from: http://www.naturallymindful.com/2014/03/homemade-calming-babypowder.html.

93. Science and Safety Behind Your Favourite Products, Baby Lotions, Oils, Powders and Creams. Cosmetics info. Available from: http:// www.cosmeticsinfo.org/products/baby-lotions-oils-powders-andcreams.

94. Science and Safety Behind your Favourite Products. Available from: http://www.cosmeticsinfo.org/ingredient/zinc-oxide.

95. Science and Safety Behind your Favourite Products. Available from: http://www.cosmeticsinfo.org/ingredient/tocopheryl-acetate.

96. Science and Safety Behind Your Favourite Products, Baby Shampoos. Available from: http://www.cosmeticsinfo.org/products/babyshampoos.

97. Science and Safety Behind Your Favourite Products, Baby Bubble Baths. Available from: http://www.cosmeticsinfo.org/products/bubblebaths.

98. Science and Safety Behind Your Favourite Products, Baby Bath Oils, Tablets and Salts. Available from: http://www.cosmeticsinfo.org/ products/bath-oils-tablets-and-salts.

99. Arumugam M, Raman M, Eagappan K. Formulation and storage stability of beta-carotene enriched Vitamin d3 and omega 3 fortified cold pressed virgin coconut oil. Int J Pharm Pharm Sci 2014;6:112-6.

100. Reddy MV, Aruna G, Parameswari SA, Banu BH, Reddy PJ. Estimated daily intake and exposure of sodium benzoate and potassium sorbate through food products in school children of Tirupati, India. Int J Pharm Pharm Sci 2015;7:129-30. 